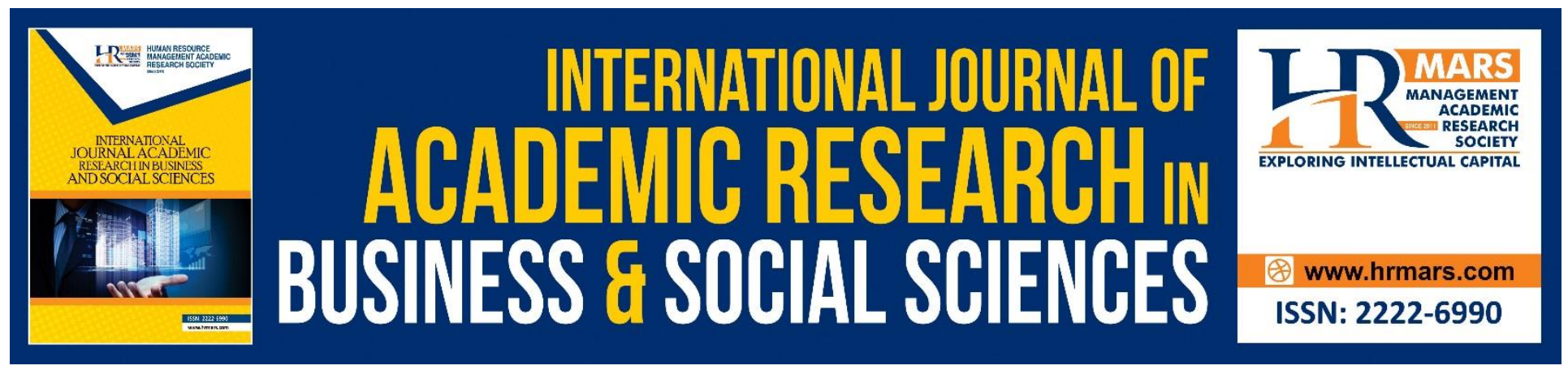

\title{
Principal Instructional Leadership and Teacher Readiness for Change to Implement School Based Assessment in Secondary Schools
}

Nor Azni Abdul Aziz, Soaib Asimiran, Foo Say Fooi, Aminuddin Hassan

To Link this Article: http://dx.doi.org/10.6007/IJARBSS/v8-i12/5008 DOI: $10.6007 /$ IJARBSS/v8-i12/5008

Received: 08 Oct 2018, Revised: 29 Nov 2018, Accepted: 11 Dec 2018

Published Online: 18 Dec 2018

In-Text Citation: (Aziz, Asimiran, Fooi, \& Hassan, 2018)

To Cite this Article: Aziz, N. A. A., Asimiran, S., Fooi, F. S., \& Hassan, A. (2018). Principal Instructional Leadership and Teacher Readiness for Change to Implement School Based Assessment in Secondary Schools. International Journal of Academic Research in Business and Social Sciences, 8(12), 221-230.

Copyright: (C) 2018 The Author(s)

Published by Human Resource Management Academic Research Society (www.hrmars.com)

This article is published under the Creative Commons Attribution (CC BY 4.0) license. Anyone may reproduce, distribute, translate and create derivative works of this article (for both commercial and non-commercial purposes), subject to full attribution to the original publication and authors. The full terms of this license may be seen

at: http://creativecommons.org/licences/by/4.0/legalcode

Vol. 8, No. 12, 2018, Pg. 221 - 230

http://hrmars.com/index.php/pages/detail/IJARBSS

JOURNAL HOMEPAGE

Full Terms \& Conditions of access and use can be found at http://hrmars.com/index.php/pages/detail/publication-ethics 


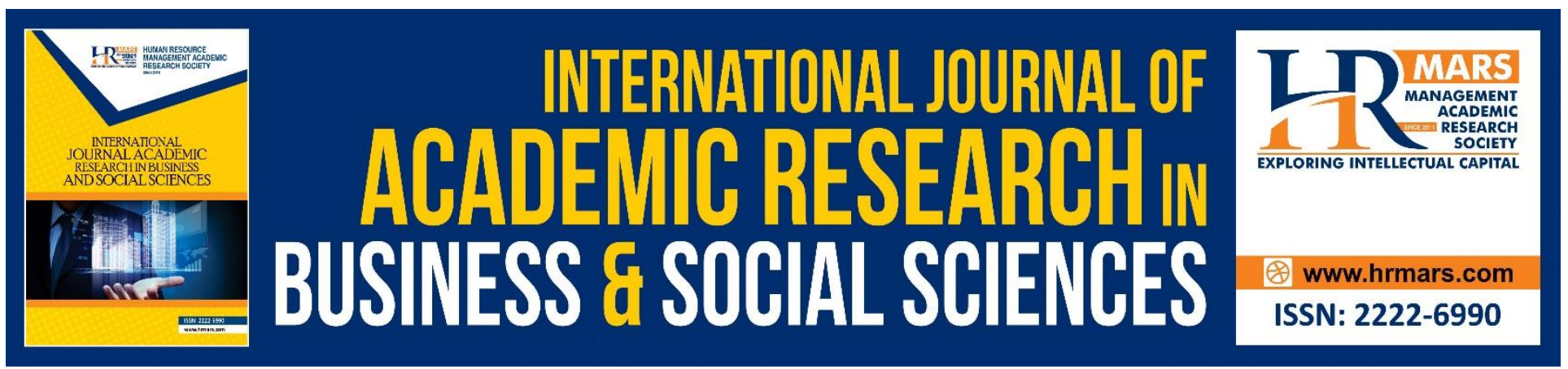

\title{
Principal Instructional Leadership and Teacher Readiness for Change to Implement School Based Assessment in Secondary Schools
}

\author{
Nor Azni Abdul Aziz, Soaib Asimiran, Foo Say Fooi, Aminuddin \\ Hassan
}

Faculty of Educational Studies, Universiti Putra Malaysia, 43400 UPM Serdang, Selangor Darul Ehsan, Malaysia

\begin{abstract}
The instructional leadership of a principal has a positive effect on teacher readiness for change. As such, the purpose of this study was to examine the relationship between three dimensions of principal instructional leadership and teacher readiness for change in implementing School-Based Assessment (SBA) among secondary school teachers in Selangor, Malaysia. A quantitative correlational design was used to collect the data using an adapted questionnaire to measure principal instructional leadership and teacher readiness for change. Data was obtained from 402 secondary teachers in Selangor, who were selected through stratified random sampling. Data was analysed using SPSS in the form of mean, standard deviation, and Pearson correlation analysis. The findings show that the level of instructional leadership of the principal as a whole is high with a mean of 3.68 and standard deviation 0.57 . The overall level of readiness for change among the teachers is high with a mean of 3.72 and standard deviation of 0.51 . Tests to determine the correlation between the dimensions of the mission of school $(r=0.321, p<0.05)$ and creating school learning climate $(r=$ $0.371, p<0.05)$ with readiness for change among the teachers show a significant positive but low correlation. Meanwhile, the relationship between managing the teaching program $(r=0.470, p<0.05)$ with readiness for change among the teachers shows a significant positive but moderate correlation. Overall, the effect of principal instructional leadership on readiness for change shows that instructional leadership has a positive and significant correlation with the readiness for change. This study provides the basis for teacher readiness to face changes and strengthening the educational administration field in enhancing instructional leadership in schools.
\end{abstract}

Keywords: School-Based Assessment (SBA), instructional leadership, readiness for change

\section{Introduction}

Education changes are taking place across the world due to globalization, liberalization and development of information technology. This has resulted in the country's education policy makers 
INTERNATIONAL JOURNAL OF ACADEMIC RESEARCH IN BUSINESS AND SOCIAL SCIENCES Vol. 8, No. 12, Dec, 2018, E-ISSN: 2222-6990 @ 2018 HRMARS

having the need to make relevant changes and improvements in education, to address the challenges of achieving global standards of educational excellence. Principals must play the role as instructional leaders who bring positive impacts in preparing teachers for educational changes. According to Berkovich (2011), education policy reform is implemented as a way to improve the operation of the school systems, processes and learning outcomes of students. However, most of the educational changes failed to be implemented effectively in the organizations including in schools because of factors such as negative emotions of teachers in particular uncertainty, fear and doubtfulness that made it difficult for teachers to accept the changes (Yan, 2012). Therefore, when there are factors of resistance to change, teachers are no longer willing to implement reforms in education, bringing negatives impacts to educational change (Fullan, 2001).

Based on the Interim Strategic Plan 2011-2020 and the Malaysia Education Development Plan (PPPM) 2013-2025 (Pelan Pembangunan Pendidikan Malaysia, 2013), the implementation of School-Based Assessment (SBA) beginning in 2011 for primary schools and 2012 for secondary schools respectively is a process of change from top-down of the Ministry of Education Malaysia (MOE) to improve the existing methods of student assessment; in order to enhance the quality of teaching and learning in schools. SBA is in line with the implementation of the national transformation programme to generate human capital that can compete globally (Pelan Pembangunan Pendidikan Malaysia, 2013). It is also a holistic form of assessment that assesses cognitive (intellectual), affective (emotional and spiritual) and psychomotor (physical) aspects, in accordance with the National Philosophy of Education (Kementerian Pendidikan Malaysia, 2012).

There is a relationship between leadership and readiness for change as have been argued by several researchers on instructional leadership (Aarons, Sommerfeld, \& Willging, 2011; Armenakis \& Harris, 2009; Boga \& Ensari, 2009; Choi, 2011; Gilley, Gilley, \& Mcmillan, 2009; Hammond, Gresch, \& Vitale, 2011; Holt, Armenakis, Harris, \& Field, 2007; Lyons, Swindler, \& Offner, 2009; Norshidah, 2011; Oreg, Vakola, \& Armenakis, 2011; Santhidran et al., 2013; Walker, Armenakis, \& Bernerth, 2007). It was also reiterated by others such as Armenakis \& Bedeian (1999), Armenakis \& Harris (2002), Foster (2010) and Holt et al. (2007) that effective leaders are able to reduce resistance to change and influence their followers towards readiness for change. As for schools' principals, their instructional leadership behavior have positive effects on teacher readiness for change (Hallinger, 2003; Hallinger \& Heck, 1998; Jainabee \& Jamelaa, 2011; Jamelaa \& Jainabee, 2011; Kursunoglu \& Tanrıgen, 2009). In short, principals are the initiators for teachers' readiness for the process of change.

Literature has emphasized that in any organization, employees must be in a state of readiness to support changes (Armenakis \& Harris, 2002). It is undeniable that instructional leadership is crucial for organizational changes. For Malaysian secondary schools, there is a need to conduct more research to examine the relationship between leadership and readiness for change (Norshidah, 2011). Additionally, studies have yet to investigate the relationship between the three dimensions of instructional leadership and school readiness for change within the organization. This relationship is important to evaluate with empirical studies, as it affects the efficiency of changes on the implementation of School Based Assessment (SBA). Therefore, the aim of this study was to 
INTERNATIONAL JOURNAL OF ACADEMIC RESEARCH IN BUSINESS AND SOCIAL SCIENCES

Vol. 8, No. 12, Dec, 2018, E-ISSN: 2222-6990 @ 2018 HRMARS

investigate the relationship between the three dimensions of instructional leadership of the principal and the readiness for change of teachers in implementing SBA changes in secondary schools.

\section{Literature Review}

Generally, leadership can be defined as the relationship between an individual and a society that is built upon common goals, where the group is behaving according to the instruction, assessment, and influence of the leader (Hoy \& Miskel, 2008). Leadership involves the process of influencing others to understand, to accept and to do the actions to be implemented effectively in order to achieve common goals. Principals are commonly seen as the instructional leaders in schools and are to encourage teachers to achieve the academic goals of the school, working more in the works, and more willing to exert effort in implementing school changes (Lahui-Ako, 2001). Instructional leadership of principals refers to the behaviors conducted with the aim of promoting and improving the teaching and learning process in schools involving teachers, students, parents, school planning, school management, resources, and culture of the school (Hallinger \& Murphy, 1985). An instructional leader is also a key factor for the success of the change in the schools and school achievement (Carrier, 2011; Sahin, 2011). It comprises the three dimensions of defining the mission of the school, managing the teaching programme, and creating a learning climate of the school. When changes occur in the education system, principals are commonly expected to provide guidance and inspire teachers to implement such changes.

Readiness for change has been defined as the comprehensive attitude influenced simultaneously by content (what changed), process (how the changes are implemented), the context (the circumstances in which the change occurs), and individual (individual-related factor) that are all involved in a change (Holt, Armenakis, Field \& Harris, 2007). Meanwhile, Armenakis, Harris \& Mossholder (1993) define readiness for change as the willingness to change beliefs, attitudes and positive intentions of someone involved to implement changes to achieve the set goals. Therefore, when someone shows supportive behavior to change due to the evaluation of thinking that drives the action, it is interpreted that the person is willing to change. Holt and Vardaman (2013) and Vakola (2013) concurred by stating that one of the important factors that affect the successful implementation of changes is early readiness for organizational change and that will only change if the members in the organization is ready to implement the changes. Therefore, the readiness for change is one of the most important constructs for the first step in the process of change, as it evaluates a person's reaction to change and it reflects whether or not they support the change. If it is accepted and understood by the employees, those involve will be more motivated and committed to provide support and implement change effectively. Conversely, if it is ignored and resist, there will be obstacles that would hinder the success of the planned change.

In organizations such as schools, when there is readiness for change among principals and teachers, the school as an organization would be willing to accept change and hence, resistance will be reduced. However, if they are not prepared, the changes that have been planned in the school will be rejected, and then they will act in negative reactions such as being hesitant, fearful, and attempting to undermine the efforts of the changes implemented (Soumyaja, Kamalanabhan \& 
Bhattacharyya, 2011). In schools, leadership of principals as instructional leader is seen as a positive impact in preparing teachers towards the change (Hallinger, 2003; Hallinger \& Heck, 1998; Jainabee \& Jamelaa, 2011; Jamelaa \& Jainabee, 2011; Kursunoglu \& Tanrıogen, 2009; Suseela \& Sim, 2010).

Effective leaders are more likely to provide support to change the basic values, beliefs, and attitudes of employees so that they are willing to accept and understand the change initiative (Santhidran et al., 2013). In addition, attitudes or practices of the leaders also play an important factor in the process of creating readiness for change of workers (Choi, 2011; Santhidran et al., 2013). In several studies by Lyons et al. (2009), Norshidah (2011) and Santhidran et al. (2013) who studied the effect of leadership on readiness for change shows that leadership has a positive and significant correlation with the readiness for change. It is therefore very important for leaders to understand the practices and the impact of leadership on workers because the first thing to be created in the process of change is the readiness for change of the employees to ensure that changes will be successfully implemented effectively (Santhidran et al., 2013).

\section{Methodology}

This is a cross-sectional study which was conducted in secondary schools in Selangor, Malaysia. The respondents were 402 teachers and sample selection was based on a stratified random sampling. The required number of samples was determined using Cochran's formula (Cochran, 1977). In order to collect data from the respondents, a questionnaire has been used comprising three parts, namely demographics, instructional leadership of the principal and the readiness for change among the teachers. The instrument was adapted from Hallinger (2003) and Holt et al. (2007) and it has been used to assess the level of instructional leadership of the principal and teacher's readiness for change. Cronbach's alpha reliability coefficient value of the entire instrument is 0.92 whereas the Cronbach's alpha reliability coefficient value for the principal instructional leadership is 0.91 and that of the readiness for change of the teachers is 0.92 . Descriptive analysis was used to obtain the mean value, frequency, and it described the standard deviation of scores for the constructs in this study to identify the level of instructional leadership of the principal and teacher's readiness to change. Meanwhile, the relationship between the two constructs has been analyzed using Pearson correlation analysis.

\section{Findings}

The findings show that the level of instructional leadership of the principal as a whole is at a high level with a mean of 3.70 and standard deviation 0.57 . The first dimension of determining the mission of the schools has the highest mean value of 3.86 and a standard deviation of 0.63 . This shows the principal's instructional leadership practices for the first dimension is at a high level. The second dimension of managing the teaching programme also shows the level of principal's instructional leadership is at a high level $(M=3.78, S D=0.59)$. As for the third dimension on creating a learning climate of the school, the value obtained for the mean and standard deviation is 3.56 and 0.83 respectively which shows that the level of instructional leadership of the principal is at a moderate level. 
INTERNATIONAL JOURNAL OF ACADEMIC RESEARCH IN BUSINESS AND SOCIAL SCIENCES

Vol. 8, No. 12, Dec, 2018, E-ISSN: 2222-6990 @ 2018 HRMARS

Table 1: Level of Principal's Instructional Leadership

\begin{tabular}{llll}
\hline Dimension of Instructional Leadership & Mean & SD & Level \\
\hline To determine school mission & 3.86 & 0.63 & High \\
To manage teaching programme & 3.78 & 0.59 & High \\
To establish school learning climate & 3.56 & 0.83 & Moderate \\
\hline Overall Level & 3.70 & 0.57 & High \\
\hline
\end{tabular}

Levels of Instructional Leadership: 1.00-2.33=Low, 2.34-3.67=Moderate, 3.67-5.00=High

Meanwhile, the overall level of readiness for change among the teachers is at a high level with a mean of 3.72 and standard deviation of 0.51 as shown in Table 2. The dimension of management support has the highest mean value of 3.87 and a standard deviation of 0.59 that shows the level of management support for the readiness for change of the teachers is at a high level. This is followed by the dimension of appropriateness of change $(M=3.71, S D=0.61)$ and it also shows respondents assess this dimension at a high level. For efficacy dimension of change $(M=3.66, S D=0.56)$ and usefulness to themselves $(M=3.65, S D=0.71)$, the findings indicate respondents' assessment is only at a moderate level.

Table 2: Levels of Readiness to Change among Teachers

\begin{tabular}{llll}
\hline Dimension of Readiness to Change & Mean & SD & Level \\
\hline Appropriateness of Change & 3.71 & 0.61 & High \\
Management Support & 3.87 & 0.59 & High \\
Efficacy of Change & 3.66 & 0.56 & Moderate \\
Usefulness to Self (Themselves) & 3.65 & 0.71 & Moderate \\
\hline Overall Level & $\mathbf{3 . 7 2}$ & $\mathbf{0 . 5 1}$ & High \\
\hline
\end{tabular}

Levels of Readiness to Change among Teachers: 1.00-2.3=Low, 2.34-3.67=Moderate, 3.67$5.00=$ High

Table 3: Relationship between Dimension of Principal's Instructional Leadership and Teacher's Readiness for Change

\begin{tabular}{ll}
\hline $\begin{array}{l}\text { Dimension of Principal's } \\
\text { Leadership }\end{array}$ & Instructional \\
\hline To determine school mission & 0.321 \\
To manage teaching programme & 0.470 \\
To establish school teaching climate & 0.371 \\
\hline
\end{tabular}

Tests to determine the correlation between the dimensions of the mission of school $(r=0.321, p$ $<0.05)$ and creating school learning climate $(r=0.371, p<0.05)$ with readiness for change among the teachers showed a significant positive but low correlation. Meanwhile, the relationship between managing the teaching programme $(r=0.470, p<0.05)$ with readiness for change among the teachers 
INTERNATIONAL JOURNAL OF ACADEMIC RESEARCH IN BUSINESS AND SOCIAL SCIENCES

Vol. 8, No. 12, Dec, 2018, E-ISSN: 2222-6990 C 2018 HRMARS

shows a significant positive but moderate correlation. This shows that when the principals have a high level of instructional leadership in the school, the readiness for change among teachers is also increased in implementing SBA.

\section{Discussion}

Overall, a high level of instructional leadership by the school principals have shown that when the principals display widespread practice of instructional leadership, by setting objectives to be achieved for SBA, manage SBA activities, and create a learning climate of the school in line with the goals of SBA, this practice encourages teachers to willingly change and accept positively to implement SBA. Previous study such as by Ang \& Ramiah (2013) has effective impacts on school effectiveness. Teachers believe in the appropriateness of changes undertaken that they understand the importance of changing to a more holistic assessment than previous assessments which are more focused on the examination alone. With clear information from time to time and guidance in implementing SBA from the principals, teachers are also becoming more willing to accept new changes imposed on them. When principals show support action in SBA amendment, teachers are also willing to support the change because it will benefit the on-going changes.

Findings from this study are consistent with those discovered by Finnigan (2010) and Chen (2013). Finnigan (2010) research was conducted in Chicago, where his research findings have shown that there is a significant relationship between instructional leadership of the principal and the readiness for change of the teachers surveyed in terms of the dimensions of teacher's efficacy in implementing any changes with regard to accountability. Chen (2013) research has found out that the principal's instructional leadership can improve the readiness for change of the ICT teachers in primary and secondary schools in Singapore. The results of both studies have shown that the principals as instructional leaders need to set goals, communicate information to teachers, influence teachers, encourage, and provide opportunities for professional development.

\section{Conclusion}

In conclusion, high level of instructional leadership of the principal increases teachers' willingness to face educational changes that occur, such as that of SBA system. Principals' high commitment and integrity are the key steering figure in school management, as well as teachers as the drivers for change. Principal as instructional leader of the school has to be the catalyst of change that will ensure schools achieve changes that are being implemented (Jainabee \& Jamelaa, 2011; Kursunoglu \& Tanrıogen, 2009), by ensuring readiness for change among teachers. This is because when teachers are ready for changes in the organization of school, this will encourage them to become committed to implement the changes. Above all, the effect of leadership on readiness for change shows that leadership has a positive and significant correlation with the readiness for change. 
INTERNATIONAL JOURNAL OF ACADEMIC RESEARCH IN BUSINESS AND SOCIAL SCIENCES

Vol. 8, No. 12, Dec, 2018, E-ISSN: 2222-6990 @ 2018 HRMARS

\section{References}

Aziz, N. A. A., Asimiran, S., Fooi, F. S., \& Hassan, A. (2018). Principal Instructional Leadership and Teacher Readiness for Change to Implement School Based Assessment in Secondary Schools. International Journal of Academic Research in Business and Social Sciences, 8(12), 221-230. 